\title{
Analysis on the Economic Spatial Linkage Gravity Model of the Urban Agglomeration in Northeast Zhejiang
}

\author{
Ying ZI \\ Ningbo city college of Vocational Technology, Ningbo City, Zhejiang Province, China \\ shadowziying@163.com
}

Keywords: Key words: Northeastern Zhejiang; Urban Agglomeration; Gravity Model; Economic Space

\begin{abstract}
According to the data of statistical yearbook, this paper calculates the influence of a city's outward function on the intensity of urban flow, so as to modify the "quality" of the gravity model and calculate the economic spatial linkage of Urban Agglomeration. The calculation shows that in the past ten years, the development of the urban agglomeration in the northeast of Zhejiang Province is very rapid, and the Hangzhou - Jiaxing - Shaoxing city cluster with Hangzhou as the center and the Ningbo - Zhoushan city cluster with the center of the Ningbo as the center have formed. The relationship between each other is also very close, and radiation influence becomes larger and larger. We should note that the urban flow strength in Shaoxing and Huzhou is slow and the extending function is weak. The urban agglomeration in Hangzhou and Huzhou has not been formed and requires acceleating the development speed.
\end{abstract}

\section{Introduction}

The area of six cities (Hangzhou City, Ningbo City, Huzhou City, Jiaxing City, Shaoxing City, Zhoushan City) in Zhejiang Province surrounding Hangzhou Bay forms Hangzhou Bay urban agglomeration in Yangtze River Delta metropolitan area. The area is called Northeastern Zhejiang in the statistical yearbook of Zhejiang because the area is located in Northeast of Zhejiang, which borders on Shanghai and Jiangsu in north, Anhui in the west, East Sea in east and Taizhou and Jinhua in south. Show in Figure 1

Many national and foreign scholars ${ }^{[1,2,3,4]}$ have used gravity model in the research on economic spatial linkage of Urban Agglomeration. The difference is how to determine the parameters in the model according to the specific object, especially how to determine the quality of the gravity model. The quality parameter is the core of gravity model, and it is the key parameter to apply the gravity model to study the economic spatial linkage of Urban Agglomeration. So researchers pay more attention to it. The most common is that the GDP or resident population of the city is used as the quality in the model ${ }^{[4]}$, and also some authors ${ }^{[2,5]}$ uses the quality combining several factors. Based on the analysis of the urban agglomeration economic spatial linkage, the paper uses the urban flow intensity as the quality of the gravity model to calculate the economic spatial linkage of the cities in the northeast of Zhejiang Province.

\section{Computation Model Construction}

\section{Gravity Model}

The general form of gravity model is ${ }^{[1,2,3,4,5]}: \quad F_{i j}=k \frac{M_{i} M_{j}}{d_{i j}^{b}}$

Where, $F_{i j}$ is the gravitation between i and $\mathrm{j}$; $M_{\mathrm{i}} M_{j}$ indicates the quality of city i and $\mathrm{j}$. the paper respectively takes the urban flow strength of each city. $d$ is the distance between $i$ and $j$; the paper takes the road distance between two cities. $\mathrm{b}$ and $\mathrm{k}$ are constant number. Referring to the literatures, b takes 2 and $\mathrm{k}$ takes 1 . 


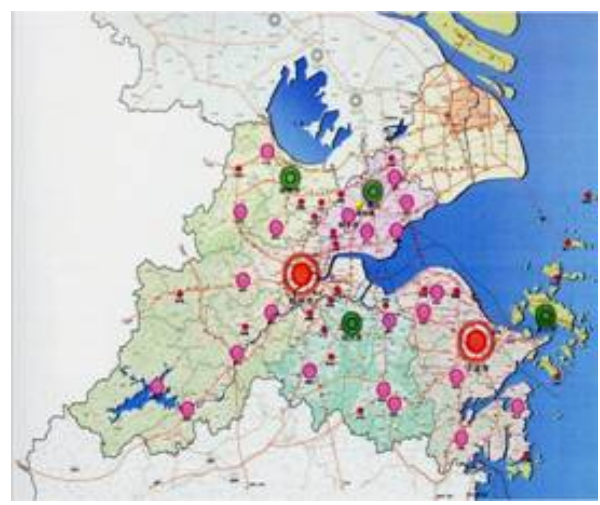

Figure.1 Area in Northeastern Zhejiang

\section{Urban Flow Model}

The calculation formula of urban flow strength is ${ }^{[6,7]} \quad F_{i}=G D P_{i} \cdot E_{i} / G_{i}$ (2). Where, $F_{i}$ is urban flow strength; $G_{i}$ is the quantity of total urban populations; $G D P_{i}$ is Gross domestic product; $E_{i}$ is total outward function of m departments of i city:

$$
E_{i}==\sum_{j=1}^{m} G_{i j} \varphi_{i j}
$$

$E_{i j}$ is the Outward function of $\mathrm{j}$ department ${ }_{\text {in i city: }} E_{i j}=G_{i j} \varphi_{i j}=G_{i j}-G_{i} \cdot\left(G_{j} / G\right)$

$$
\varphi_{i j} \text { is Specialization coefficient: } \varphi_{i j}=1-1 / S_{i j}
$$

$G_{i j}$ is the employed population of $\mathrm{j}$ department in i city; $G_{j}$ is the quantity of employed populations of $\mathrm{j}$ department; $\mathrm{G}$ is Total national population. $\mathrm{m}$ is the number of indicators describing Northeast Zhejiang economic spatial linkage .

$$
\text { In formula(2), }
$$$$
K_{i}=E_{i} / G_{i}
$$

It indicates the outward function provided by unit population. It is defined as urban flow tendency[7].

As for the selection of indicators, refer to the strength on urban flow intensity of Urban Agglomeration in relevant literatures. Research intercity flow intensity with the indicator of number of employed populations in transportation and telecommunications, wholesale and retail, finance, real estate, social services, educational and Cultural Broadcasting, scientific research, manufacturing industry.

According to the above calculation model, calculate the urban flow intensity of cities in Northeast Zhejiang and their economic spatial linkage with the statistical data in State Statistical Bureau and Statistics Bureau of Zhejiang Province.

\section{Calculation Results and Analysis}

\section{Specialization Coefficient}

Specialization coefficient indicates the level of specialization of an industrial sector. If larger than 0 , it indicates the industry department should provide services to the outside in addition to meeting the urban requirements, namely there is certain outward function. If less than 0 , it indicates the industry department cannot meet the urban requirements but not providing outward services, namely there is no outward function [11]. Table 1 lists the specialization coefficient of cities in Northeast Zhejiang Province in 2014. The calculation indicates the industry departments with specialization coefficient less than 0 exist in Jiaxing, Ningbo and Zhoushan. It indicates they have higher outward function and the external influence is stronger. Where, the specialization coefficient is especially outstanding 
in Zhoushan City. Especially in technology, services, transportation and other departments, it has higher industrial concentration and strong outward function. As shown in urban flow tendency $\mathrm{K}$ in table 1, it indicates the outward energy provided by unit population in Zhoushan City is higher than other cities.

Table 1, The specialization coefficient and urban flow tendency of the cities in Northeast Zhejiang Province in 2014

\begin{tabular}{|c|c|c|c|c|c|c|c|c|c|}
\hline City & $\begin{array}{l}\text { Manufact } \\
\text { uring } \varphi\end{array}$ & Traffic & $\begin{array}{l}\text { Wholes } \\
\text { ales }\end{array}$ & $\begin{array}{l}\text { Financ } \\
\mathrm{e}\end{array}$ & $\begin{array}{l}\text { Real } \\
\text { estate }\end{array}$ & $\begin{array}{l}\text { Servic } \\
\text { es }\end{array}$ & $\begin{array}{l}\text { Educatio } \\
\mathrm{n}\end{array}$ & $\begin{array}{l}\text { Science } \\
\text { and } \\
\text { technol } \\
\text { ogy }\end{array}$ & $K$ \\
\hline $\begin{array}{l}\text { Hangzho } \\
\text { u }\end{array}$ & 0.6117 & 0.610 & 0.747 & 0.6907 & $\begin{array}{l}0.781 \\
2\end{array}$ & $\begin{array}{l}0.765 \\
0\end{array}$ & 0.5040 & 0.7984 & 0.1821 \\
\hline Ningbo & 0.7075 & 0.4089 & 0.4605 & 0.6605 & $\begin{array}{l}0.324 \\
2\end{array}$ & $\begin{array}{l}0.576 \\
3\end{array}$ & 0.1934 & 0.0602 & 0.1441 \\
\hline Jiaxing & 0.72354 & $\begin{array}{l}-0.147 \\
9\end{array}$ & 0.0953 & 0.3037 & $\begin{array}{l}0.404 \\
8\end{array}$ & $\begin{array}{l}0.390 \\
6\end{array}$ & 0.1962 & -0.3065 & 0.1169 \\
\hline Huzhou & 0.4676 & $\begin{array}{l}-0.845 \\
8\end{array}$ & 0.1992 & 0.3614 & $\begin{array}{l}-0.04 \\
8\end{array}$ & $\begin{array}{l}-0.246 \\
0\end{array}$ & -0.0469 & -0.6690 & 0.045 \\
\hline $\begin{array}{l}\text { Shaoxin } \\
\text { g }\end{array}$ & 0.5434 & $\begin{array}{l}-0.800 \\
1\end{array}$ & $\begin{array}{l}-0.128 \\
7\end{array}$ & 0.2692 & $\begin{array}{l}-0.67 \\
0\end{array}$ & -0.465 & 0.0477 & -0.7991 & 0.05 \\
\hline $\begin{array}{l}\text { Zhousha } \\
\text { n }\end{array}$ & 0.634 & 0.8087 & 0.9097 & 0.5613 & 0.727 & 0.919 & 0.3392 & 0.6684 & 0.3438 \\
\hline
\end{tabular}

\section{Urban flow Strength}

Table 2 lists the Calculation results of urban flow intensity in Northeast Zhejiang in 2006 - 2014. Figure 2 is drawn according to the structure of table 2. It can be seen from the calculation results of urban flow intensity that he outward function of the cities in the northeast of Zhejiang Province has been improved to some extent in the past ten years, namely the outward influence is enhanced continuously. In contrast, the growth speed in Hangzhou and Ningbo is faster and the speed in Zhoushan is the fastest after 2012. It reflects Hangzhou and Ningbo city have stronger radiation impact. It is proved that the construction of Zhoushan and Shanghai and Ningbo City Sea crossing bridge has great effect on the economic and social development of Zhoushan.

Table 2,The urban flow intensity of cities in Northeast Zhejiang in 2006 - 2014 (RMB 0.1 billion)

\begin{tabular}{|c|c|c|c|c|c|}
\hline City & 2006 & 2008 & 2010 & 2012 & 2014 \\
\hline Hangzhou & 458.4972 & 701.9606 & 1073.207 & 1469.203 & 1676.763 \\
\hline Ningbo & 220.5081 & 377.9767 & 648.2533 & 953.9725 & 1096.768 \\
\hline Jiaxing & 193.0493 & 240.5618 & 332.0563 & 359.3672 & 392.0352 \\
\hline Huzhou & 29.29754 & 53.0052 & 77.2580 & 63.52372 & 87.63953 \\
\hline Shaoxing & 42.82747 & 165.0099 & 200.8127 & 177.9210 & 213.2129 \\
\hline Zhoushan & 16.71657 & 19.2801 & 42.91441 & 37.37986 & 349.0029 \\
\hline
\end{tabular}




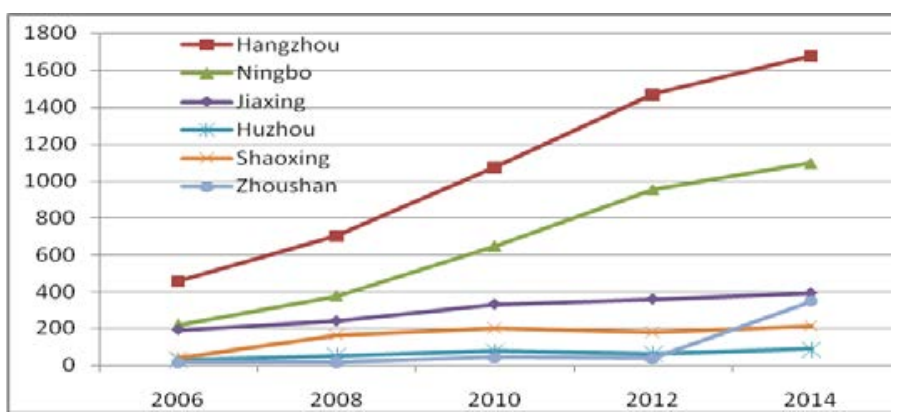

Figure.2 The change of urban flow intensity in different cities in Northeast Zhejiang in 2006-2014

In contrast, the urban flow strength in Shaoxing and Huzhou grows slowly. Both cities are weak in outward function and low in radiation influence. They are at the end of Hangzhou Bay urban agglomeration. Jiaxing and Zhoushan are second to them and in the middle end of Hangzhou Bay urban agglomeration. Although Zhoushan City has small population size and social economic aggregate, the urban flow strength has exceeded Shaoxing City and Huzhou City where the population scale is far larger than Zhoushan. Hangzhou and Ningbo are located in the center of Northeast Zhejiang Urban Agglomeration and its radiation impact is far higher than other cities in the agglomeration.

\section{Economic Spatial linkage}

Statistical yearbook data are used the calculate Northeast Zhejiang Urban Agglomeration Economic Spatial Linkage gravity in 2006, 2010 and 2014 according to formula (1), as shown in table 3, 4 and 5 . The calculation results are sequenced according to the gravity size.

Table 3, Sequence of Economic spatial linkage of Northeast Zhejiang Urban Agglomeration in 2014

\begin{tabular}{|l|l|l|l|l|l|}
\hline City & $\begin{array}{l}\text { Calculated } \\
\text { gravity }\end{array}$ & City & $\begin{array}{l}\text { Calculated } \\
\text { gravity }\end{array}$ & City & $\begin{array}{l}\text { Calculated } \\
\text { gravity }\end{array}$ \\
\hline $\begin{array}{l}\text { Hangzhou - } \\
\text { Jiaxing }\end{array}$ & 86.84768 & Ningbo-Jiaxing & 19.62982 & $\begin{array}{l}\text { Jiaxing-Zhous } \\
\text { han }\end{array}$ & 2.776183 \\
\hline $\begin{array}{l}\text { Hangzhou } \\
\text {-Shaoxing }\end{array}$ & 84.61716 & Ningbo-Shaoxing & 16.51332 & $\begin{array}{l}\text { Shaoxing-Zho } \\
\text { ushan }\end{array}$ & 2.018553 \\
\hline $\begin{array}{l}\text { Hangzhou - } \\
\text { Ningbo }\end{array}$ & 75.56788 & $\begin{array}{l}\text { Hangzhou } \\
\text {-Zhoushan }\end{array}$ & 11.06229 & $\begin{array}{l}\text { Ningbo-Huzho } \\
\text { u }\end{array}$ & 1.74052 \\
\hline $\begin{array}{l}\text { Ningbo-Zhoush } \\
\text { an }\end{array}$ & 50.57144 & Jiaxing-Shaoxing & 7.035347 & $\begin{array}{l}\text { Huzhou-Shaox } \\
\text { ing }\end{array}$ & 0.876613 \\
\hline $\begin{array}{l}\text { Hangzhou } \\
\text {-Huzhou }\end{array}$ & 22.39761 & Jiaxing-Huzhou & 5.109723 & $\begin{array}{l}\text { Huzhou-Zhous } \\
\text { han }\end{array}$ & 0.324528 \\
\hline
\end{tabular}

Table 4,Sequence of Economic spatial linkage in Northeast Zhejiang Urban Agglomeration in 2010

\begin{tabular}{|l|l|l|l|l|l|}
\hline City & $\begin{array}{l}\text { Calculated } \\
\text { gravity }\end{array}$ & City & $\begin{array}{l}\text { Calculated } \\
\text { gravity }\end{array}$ & City & $\begin{array}{l}\text { Calculated } \\
\text { gravity }\end{array}$ \\
\hline $\begin{array}{l}\text { Hangzhou } \\
\text {-Shaoxing }\end{array}$ & 51.00913 & $\begin{array}{l}\text { Ningbo-Shao } \\
\text { xing }\end{array}$ & 9.192677 & $\begin{array}{l}\text { Hangzhou } \\
\text {-Zhoushan }\end{array}$ & 0.870625 \\
\hline $\begin{array}{l}\text { Hangzhou } \\
\text {-Jiaxing }\end{array}$ & 47.0822 & $\begin{array}{l}\text { Jiaxing-Shao } \\
\text { xing }\end{array}$ & 5.612417 & $\begin{array}{l}\text { Huzhou-Shaox } \\
\text { ing }\end{array}$ & 0.727828 \\
\hline $\begin{array}{l}\text { Hangzhou } \\
\text {-Ningbo }\end{array}$ & 28.58769 & $\begin{array}{l}\text { Jiaxing-Huzh } \\
\text { ou }\end{array}$ & 3.815289 & $\begin{array}{l}\text { Jiaxing-Zhoush } \\
\text { an }\end{array}$ & 0.28914 \\
\hline $\begin{array}{l}\text { Hangzhou } \\
\text {-Huzhou }\end{array}$ & 12.63738 & $\begin{array}{l}\text { Ningbo-Zhou } \\
\text { shan }\end{array}$ & 3.67544 & $\begin{array}{l}\text { Shaoxing-Zhou } \\
\text { shan }\end{array}$ & 0.233772 \\
\hline $\begin{array}{l}\text { Ningbo-Jiaxi } \\
\text { ng }\end{array}$ & 9.827273 & $\begin{array}{l}\text { Ningbo-Huz } \\
\text { hou }\end{array}$ & 0.906886 & $\begin{array}{l}\text { Huzhou-Zhous } \\
\text { han }\end{array}$ & 0.035178 \\
\hline
\end{tabular}


Table 5,Sequence of Economic spatial linkage in Northeast Zhejiang Urban Agglomeration in 2006

\begin{tabular}{|l|l|l|l|l|l|}
\hline City & $\begin{array}{l}\text { Calculate } \\
\text { d gravity }\end{array}$ & City & $\begin{array}{l}\text { Calculate } \\
\text { d gravity }\end{array}$ & City & $\begin{array}{l}\text { Calculate } \\
\text { d gravity }\end{array}$ \\
\hline $\begin{array}{l}\text { Hangzhou } \\
\text {-Jiaxing }\end{array}$ & 11.69409 & $\begin{array}{l}\text { Ningbo-Jiaxin } \\
\text { g }\end{array}$ & 0.72091 & $\begin{array}{l}\text { Ningbo-Huzho } \\
\text { u }\end{array}$ & 0.11698 \\
\hline $\begin{array}{l}\text { Hangzhou } \\
\text {-Shaoxing }\end{array}$ & 4.64764 & $\begin{array}{l}\text { Ningbo-Shao } \\
\text { xing }\end{array}$ & 0.66689 & $\begin{array}{l}\text { Huzhou-Shaox } \\
\text { ing }\end{array}$ & 0.05886 \\
\hline $\begin{array}{l}\text { Hangzhou } \\
\text {-Ningbo }\end{array}$ & 4.15444 & $\begin{array}{l}\text { Ningbo-Zhou } \\
\text { shan }\end{array}$ & 0.48701 & $\begin{array}{l}\text { Jiaxing-Zhous } \\
\text { han }\end{array}$ & 0.03337 \\
\hline $\begin{array}{l}\text { Hangzhou } \\
\text {-Huzhou }\end{array}$ & 2.04738 & $\begin{array}{l}\text { Jiaxing-Shaox } \\
\text { ing }\end{array}$ & 0.35785 & $\begin{array}{l}\text { Shaoxing-Zho } \\
\text { ushan }\end{array}$ & 0.01942 \\
\hline $\begin{array}{l}\text { Jiaxing-Huz } \\
\text { hou }\end{array}$ & 0.84115 & $\begin{array}{l}\text { Hangzhou } \\
\text {-Zhoushan }\end{array}$ & 0.14489 & $\begin{array}{l}\text { Huzhou-Zhous } \\
\text { han }\end{array}$ & 0.00520 \\
\hline
\end{tabular}

As shown in the calculation results, the economic spatial linkage in Northeast Zhejiang Urban Agglomeration was weak in 2006. It is not fully formed in Hangzhou and Ningbo as the center of the metropolitan area. Hangzhou - Jiaxing urban cluster came into being. Huzhou and Zhoushan are located at the east and west ends of the area, where the economic spatial linkage is smaller and the mutual influence is weak. In addition to Hangzhou, the economic spatial linkage with other cities is very weak. After four years' development, Hangzhou - Jiaxing - Shaoxing urban cluster has been formed basically in 2010, economic spatial linkage in Hangzhou and Ningbo increases rapidly, the radiation influence of central city becomes prominent gradually, and Ningbo - Zhoushan cluster has been formed. By 2014, after four years' development, the economic linkage of the urban agglomeration in northeastern Zhejiang Province has developed to a higher level. The contact gravity level between Huzhou and Zhoushan in the east and west ends of the area has been developed to a higher level, which is equal to the contact level between Jiaxing and Shaoxing in 2996. Hangzhou - Jiaxing - Shaoxing urban cluster, and Ningbo -Zhoushan urban cluster centering on Hangzhou and Ningbo have been formed. The contact is very close and the radiation influence becomes larger and larger.

Table 6 lists the calculation results of economic spatial linkage in Hangzhou and other cities in Southern Zhejiang in 2006-2014.

Table 6, Economic spatial linkage in Hangzhou and other cities in Southern Zhejiang

\begin{tabular}{|c|c|c|c|c|c|}
\hline City & 2006 & 2008 & 2010 & 2012 & 2014 \\
\hline $\begin{array}{c}\text { Hangzhou } \\
\text {--Ningbo }\end{array}$ & 4.154436 & 10.90256 & 28.58769 & 57.59284 & 75.56788 \\
\hline $\begin{array}{c}\text { Hangzhou } \\
-- \text { Jiaxing }\end{array}$ & 11.69409 & 22.31007 & 47.0822 & 69.75603 & 86.84768 \\
\hline $\begin{array}{c}\text { Hangzhou } \\
\text {--Huzhou }\end{array}$ & 2.047377 & 5.67102 & 12.63738 & 14.22485 & 22.39761 \\
\hline $\begin{array}{c}\text { Hangzhou } \\
\text {--Shaoxing }\end{array}$ & 4.647639 & 27.41549 & 51.00913 & 61.87031 & 84.61716 \\
\hline $\begin{array}{c}\text { Hangzhou } \\
-- \text {-Zhoushan }\end{array}$ & 0.144887 & 0.255839 & 0.870625 & 1.038159 & 11.06229 \\
\hline
\end{tabular}




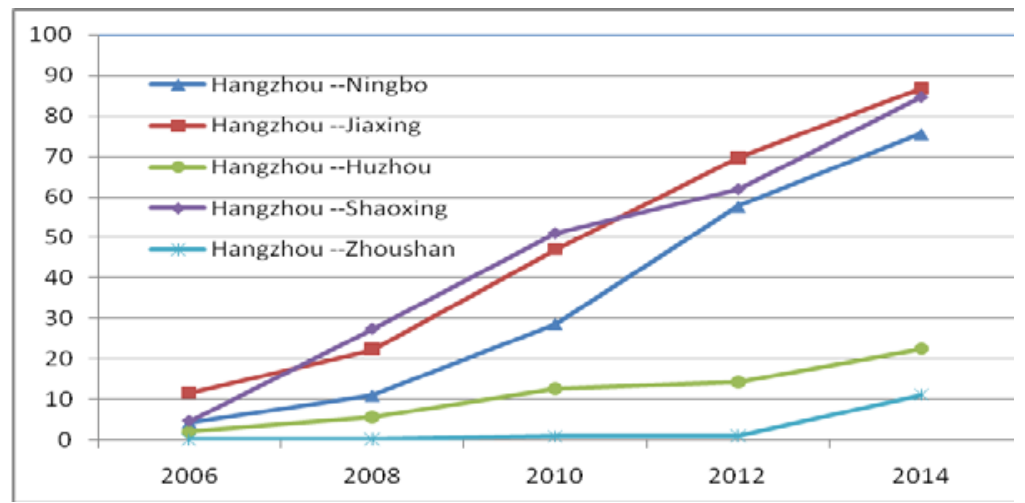

Figure.3 Changes in Economic spatial linkage in Hangzhou and Other cities in Northeast Zhejiang

Figure 3 is the figure of Changes in Economic spatial linkage in Hangzhou and Other cities in Northeast Zhejiang in 2006-2014. It is shown that since 2006, Economic spatial linkage has been growing in higher level in Hangzhou, Jiangxing, Shaoxing and Ningbo. Hangzhou - Jiaxing Shaoxing urban cluster formed after 2010 makes the urban connection closer. Economic spatial linkage grew slowly in Hangzhou, Huzhou and Zhoushan. Because the spatial distance is far away, the Economic spatial linkage in Hangzhou - Zhoushan is week. Because Huzhou is weak in urban outward functions and Hangzhou - Huzhou urban cluster has not been formed, the development speed is to be increased further.

\section{Acknowledgement}

This research was financially supported by the Department of Education of Zhejiang Province Common Science and technology project Foundation.

\section{References:}

[1]..Shen Huaifei, Hou Gang, Tian Jinlei: Strength analysis of economic ties in Zhongyuan Urban Agglomeration based on gravity model [J]. Hubei Agricultural Sciences, 2014,53(4): 989-992.

[2].Guan Xiaoguang, Liu Liu: Spatial linkage analysis of Beijing Tianjin Hebei Urban Agglomeration Based on Modified Gravity Model [J]. Urban Problems, 2014, 232(11):21-26.

[3].Cheng Danrun, Li Jing: Research on the relationship of urban economy in the construction of provincial capital economic circle - Empirical analysis based on Gravity Model [J], Science \& Technology and Economy, 2008,21(1):42-44.

[4].Li Hongjin, Li Shenghui: Research on economic spatial linkage of Urban Agglomeration Based on Gravity Model - An empirical study on the Pearl River Delta Urban Agglomeration [J]. Journal of South China University of Technology (Social Science Edition), 2011,13(1):19-24.

[5].Zi Ying, Li Jiqiu: Research on the economic spatial linkage between Ningbo city and county [J] Journal of Ningbo University of Technology, 2016(3).

[6].Zi Ying: A study on the urban flow of northeast Zhejiang Urban Agglomeration [J]. Logistics Technology 2014, 34 (11): 127-129.

[7].Zhu Yingming, Yu Nianwen: Research on city flow in intensive area of Shanghai, Nanjing and Hangzhou [J], Urban Planning Forum, 2002,(1) :31—33.

[8].Zhang Hongou, Ye Yuyao, Luo Xiaoyun: Study on urban flow intensity of urban agglomeration in the Pearl River Delta [J] Areal Research and Development, 2004,23(6):53-56.

[9].National Bureau of Statistics, 2014 China Statistical Yearbook [Z] Beijing: China Statistics Press, 2015. 
[10].Zhejiang Provincial Bureau of Statistics, Zhejiang statistical yearbook - 2014 [Z], Beijing: China Statistics Press, 2015.

[11].Zhang Zhiming, Cao Jue: Feasibility analysis of composite index location quotient method [J], Economic theory research, 2008,(11):12-13.9. 